\title{
Dorota Wyszkowska
}

Urząd Statystyczny w Białymstoku

Uniwersytet w Białymstoku

d.wyszkowska@stat.gov.pl

\section{Helena Artemiuk}

Urząd Statystyczny w Białymstoku

h.artemiuk@stat.gov.pl

\section{Anna Godlewska}

Urząd Statystyczny w Białymstoku

a.godlewska@stat.gov.pl

\section{Ujęcie jakości życia w badaniu stanu zielonej gospodarki}

Artykuł nadesłany: 22 czerwca 2017 r.; artykuł zaakceptowany: 15 grudnia 2017 r.

JEL Classification: Q01, Q56, Q58

Keywords: green economy, quality of life, monitoring indices

\section{Abstract \\ Quality of life in green economy survey}

Nature is a source of everything that surrounds us. Resources of our planet are, however, limited and the rate at which they are used leads to negative consequences not only for the globe, but also for its inhabitants. Pressure on environment is so great that it threatens the supply of resources to satisfy the residents' needs and their wellbeing. Only responsible activity of humans in terms of development perspectives may limit excessive exploitation of natural environment and preserve it for future generations, while simultaneously lead to economic growth and development. One of such perspectives is the introduction of ,green economy". It is a set of activities undertaken to increase economic growth while taking due care of environment. "Green economy" involves monitoring of the efficiency of the aforementioned activities and of the state of greening the economy. Polish public statistics has put forth a set of measurements which can be used for this monitoring.

The aim of this article is to evaluate the quality of life in Poland with the use of specially selected set of indices used to assess the state of green economy. This work consists of two parts. The first presents both theoretical aspects of green economy and indices to measure it. The other, however, focuses on Poland against the background of a selected group of indices, which can describe and assess the quality of life of Polish residents.

Ekonomia — Wroclaw Economic Review 23/4 (2017)

(C) for this edition by CNS 


\section{Wprowadzenie}

Jakość życia oraz zdrowie człowieka w znacznej mierze zależą od stanu środowiska. Jednak tempo i sposób, w jaki wykorzystywane są zasoby naturalne Ziemi, mogą przyczynić się do pogorszenia dobrobytu mieszkańców naszej planety i możliwości zaspokajania stale rosnących potrzeb. W celu zapobieżenia nadmiernemu wykorzystywaniu środowiska naturalnego w procesach rozwojowych rozpoczęto poszukiwanie nowych dróg wzrostu i rozwoju społeczno-gospodarczego, uwzględniających potrzeby związane z ochroną środowiska i zapobieganiem niekorzystnym skutkom działalności człowieka (OECD 2011, s. 6-8). Jedną z nich jest koncepcja „zielonej gospodarki”, zgodnie z którą podejmowanie działań mających na celu wzrost gospodarczy powinno być powiązane z troską o środowisko, polegającą na zrównoważonym korzystaniu z kapitału przyrodniczego, zachowaniu zdolności ekosystemów do świadczenia określonych usług oraz zapewnieniu dobrej jakości elementów środowiska, niepowodujących negatywnych oddziaływań na zdrowie i życie ludzi.

Wraz z coraz szerszym zastosowaniem tego podejścia do rozwoju pojawiła się potrzeba wypracowania sposobów pomiaru postępu w ,zazielenianiu” gospodarek. W Polsce statystyka publiczna, korzystając z doświadczeń międzynarodowych, opracowała zestaw wskaźników służących do opisu stanu „zazielenienia” gospodarki.

Celem artykułu jest przedstawienie wybranego zestawu miar stosowanych w badaniu stanu zielonej gospodarki, które mogą być jednocześnie wykorzystane do oceny jakości życia. Artykuł podzielono na dwie części. W pierwszej przedstawiono zagadnienia teoretyczne dotyczące zielonej gospodarki oraz wskaźniki służące do jej pomiaru. Druga zaś została poświęcona zaprezentowaniu sytuacji Polski w zakresie wybranej grupy wskaźników, które mogą służyć opisowi i ocenie jakości życia ludności.

\section{Ujęcie definicyjne zielonej gospodarki i jakości życia}

Polska statystyka publiczna, bazując na dorobku Organizacji Współpracy Gospodarczej i Rozwoju (OECD - Organisation for Economic Cooperation and Development) oraz innych organizacji środowiskowych, jak Program Ochrony Środowiska Narodów Zjednoczonych (UNEP - United Nations Environment Programme) oraz Europejska Agencja Środowiska (EEA — European Environment Agency), dostosowała definicję zielonej gospodarki do polskich uwarunkowań, określiła obszary ją tworzące oraz przygotowała zestaw wskaźników służących do jej monitorowania. 
Mianem zielonej gospodarki określono gospodarkę, która wspiera wzrost i rozwój gospodarczy przy jednoczesnym utrzymaniu dostępu do kapitału naturalnego i usług ekosystemowych, od których zależy dobrostan człowieka (OECD 2011, s. 9).

Badanie zazielenienia gospodarki w Polsce obejmuje przede wszystkim ocenę stanu środowiska przyrodniczego oraz efektywności gospodarowania. Aspekt społeczny ujmowany jest natomiast w węższym zakresie — jedynie w tej części, która pozostaje w bezpośrednim związku ze środowiskiem lub gospodarką (US Białystok 2016, s. 9). Podstawę funkcjonowania gospodarki i społeczeństwa stanowi bowiem środowisko, a rozwoju gospodarki — społeczeństwo. Pomiędzy tymi elementami (środowiskiem, gospodarką i społeczeństwem) zachodzą określone relacje, które posłużyły do wyodrębnienia czterech obszarów do monitorowania stanu zielonej gospodarki w Polsce:

1. kapitału naturalnego — obejmującego wskaźniki opisujące stan środowiska przyrodniczego;

2. środowiskowej efektywności produkcji — w ramach tej grupy ujęte zostały wskaźniki obrazujące powiązania między środowiskiem przyrodniczym a gospodarką;

3. środowiskowej jakości życia ludności — prezentującej wskaźniki służące monitorowaniu powiązań między środowiskiem przyrodniczym a społeczeństwem;

4. polityk gospodarczych i ich następstw — obejmujących wskaźniki charakteryzujące instrumenty oddziaływania na gospodarkę i społeczeństwo, kreujące pożądane kierunki rozwoju, mające na celu zazielenienie gospodarki (US Białystok 2016, s. 10).

W badaniu zielonej gospodarki można odnaleźć elementy kształtujące jakość życia, która jest bardzo złożoną, trudną do jednoznacznej interpretacji kategorią filozoficzną. Jest wypadkową zarówno obiektywnych uwarunkowań, jak i subiektywnych odczuć, które towarzyszą człowiekowi przez całe jego życie. Każda osoba może oceniać jakość swojego życia odmiennie, albowiem rozumie ją w inny sposób i bierze pod uwagę różne wartości. Jakość życia może być więc rozumiana jako poziom satysfakcji, jaki odczuwa jednostka w wyniku użycia dóbr i usług nabywanych na rynku, form spędzania wolnego czasu i pozostałych charakterystyk środowiska, w którym się znajduje (Gillingham, Reece 1980). Może być ona również definiowana jako dobrobyt czy konsumpcja, aż po niekwantyfikowalne stany osobistego zadowolenia, satysfakcji czy wręcz szczęścia, płynącego z konsumpcji, korzystania ze środowiska przyrodniczego, dobrego stanu zdrowia lub pozycji społecznej. To stopień satysfakcji (zadowolenia) człowieka (społeczeństwa) z całokształtu egzystencji. Jest zatem swoistą sumą indywidualnego lub zbiorowego odczucia istniejących warunków życia i zarazem ich oceną (Słaby 1990, s. 8).

Uwzględniając wieloaspektowość i niejednolitość definicyjną jakości życia, w niniejszym opracowaniu analizie zostały poddane wskaźniki wykorzystywane 
w badaniu stanu zielonej gospodarki, które mogą zostać użyte do analizy i oceny jakości życia ludności. Wskaźniki te pochodzą ze wszystkich czterech wyodrębnionych obszarów badania zielonej gospodarki, których wykaz został ujęty w tabeli 1 .

Tabela 1. Wskaźniki jakości życia w badaniu zielonej gospodarki

\begin{tabular}{|c|c|c|}
\hline Zagadnienie & Grupa wskaźników & Nazwa wskaźnika \\
\hline \multicolumn{3}{|c|}{ Kapital naturalny } \\
\hline $\begin{array}{l}\text { Bioróżnorodność } \\
\text { i stan ekosystemów }\end{array}$ & $\begin{array}{l}\text { Użytkowanie } \\
\text { gruntów }\end{array}$ & Zmiany użytkowania gruntów* \\
\hline \multirow{2}{*}{ Zasoby odnawialne } & Lesistość & Lesistość w krajach UE \\
\hline & Zasoby wody słodkiej & Wskaźnik eksploatacji wody (WEI) \\
\hline \multicolumn{3}{|c|}{ Środowiskowa jakość życia } \\
\hline \multirow{8}{*}{$\begin{array}{l}\text { Stan środowiska } \\
\text { a zdrowie ludności }\end{array}$} & \multirow{2}{*}{$\begin{array}{l}\text { Pyłowe } \\
\text { zanieczyszczenie } \\
\text { powietrza }\end{array}$} & $\begin{array}{l}\text { Wskaźnik średniego narażenia ludności na pył } \\
\mathrm{PM}_{2,5}{ }^{*}\end{array}$ \\
\hline & & $\begin{array}{l}\text { Przedwczesne zgony na skutek zanieczyszczenia } \\
\text { powietrza pyłem } \mathrm{PM}_{2,5}\end{array}$ \\
\hline & \multirow{2}{*}{$\begin{array}{l}\text { Gazowe } \\
\text { zanieczyszczenie } \\
\text { powietrza }\end{array}$} & $\begin{array}{l}\text { Średnia liczba dni z przekroczeniami wartości } \\
120 \mu \mathrm{g} / \mathrm{m}^{3} \text { przez stężenia } 8 \text {-godzinne ozonu } \\
\text { według typu stacji pomiarowej* }\end{array}$ \\
\hline & & $\begin{array}{l}\text { Przedwczesne zgony na skutek zanieczyszczenia } \\
\text { powietrza ozonem }\end{array}$ \\
\hline & \multirow{4}{*}{ Hałas } & $\begin{array}{l}\text { Odsetek zakładów przekraczających dopuszczalne } \\
\text { poziomy w zakresie hałasu przemysłowego* }\end{array}$ \\
\hline & & $\begin{array}{l}\text { Odsetek osób narażonych na hałas drogowy } \\
\text { w aglomeracjach powyżej } 100 \text { tys. mieszkańców* }\end{array}$ \\
\hline & & $\begin{array}{l}\text { Odsetek osób narażonych na hałas drogowy } \\
\text { w aglomeracjach powyżej } 100 \text { tys. mieszkańców } \\
\text { w poszczególnych klasach poziomów dźwięku* }\end{array}$ \\
\hline & & $\begin{array}{l}\text { Odsetek gospodarstw domowych odczuwających } \\
\text { nadmierny hałas* }\end{array}$ \\
\hline \multicolumn{3}{|c|}{ Środowiskowa efektywność produkcji } \\
\hline Gazy cieplarniane & $\begin{array}{l}\text { Emisje gazów } \\
\text { cieplarnianych }\end{array}$ & Emisje gazów cieplarnianych \\
\hline \multicolumn{3}{|c|}{ Polityki gospodarcze i ich następstwa } \\
\hline Rolnictwo & $\begin{array}{l}\text { Gospodarstwa } \\
\text { ekologiczne }\end{array}$ & $\begin{array}{l}\text { Gospodarstwa ekologiczne i powierzchnia } \\
\text { ekologicznych użytków rolnych* }\end{array}$ \\
\hline
\end{tabular}

* Dane dostępne wyłącznie na poziomie krajowym.

Źródło: opracowanie własne w ramach pracy metodologicznej realizowanej w Urzędzie Statystycznym w Białymstoku.

Część wskaźników zamieszczonych w tabeli 1 może być zaprezentowana nie tylko dla Polski, lecz także dla innych krajów Unii Europejskiej, co pozwala na dokonanie porównań międzynarodowych. 


\section{Jakość życia w Polsce na tle krajów Unii Europejskiej w badaniu zielonej gospodarki}

W celu oceny wpływu środowiska przyrodniczego na jakość życia społeczeństwa należy przyjrzeć się kształtowaniu miar odnoszących się do gospodarowania odnawialnymi zasobami naturalnymi, użytkowania gruntów, rolnictwa ekologicznego, pyłowego i gazowego zanieczyszczenia powietrza oraz kwestiom dotyczącym emisji gazów cieplarnianych jako niekorzystnego efektu działalności człowieka.

Gleba stanowi ważny składnik zasobów naturalnych, a sposób użytkowania gruntów wpływa na jej pokrycie i jakość, oddziałuje też na jakość wód i powietrza, a w konsekwencji — na jakość życia ludzi. Ponadto zmiany w użytkowaniu gruntów pokazują, w jaki sposób zmienia się przestrzeń, w której żyjemy. Wzrost terenów zabudowanych i zurbanizowanych to nowe miejsca do osiedlania się ludzi, ale jednocześnie pozbawianie człowieka terenów przeznaczonych na działalność rolniczą czy leśną. Problemem pozostaje wyznaczenie optymalnej struktury użytkowania powierzchni ziemi, która pozwalałaby na zaspokajanie potrzeb człowieka, a jednocześnie zapewniała samoregulację środowiska naturalnego, zapobiegając niekorzystnym zjawiskom, na przykład powodziom, osuwiskom.

Ze względu na wprowadzone zmiany w zakresie klasyfikowania poszczególnych kategorii gruntów (nowa ewidencja gruntów z 2001 roku) analiza w tym zakresie została podzielona na dwa okresy. Jak wynika z danych przedstawionych na rysunku 1, w latach 1990-2001 oraz 2002-2016 zwiększyła się powierzchnia obszarów zabudowanych i zurbanizowanych odpowiednio o 3,7\% i 10,2\% oraz gruntów leśnych, zadrzewionych i zakrzewionych o 2,8\% i 6,2\%, kosztem pozostałych terenów i użytków rolnych.

Lasy mają bardzo ważne znaczenie ekologiczne i szeroki zakres funkcji ekosystemowych, to jest ochronę przed erozją gleby i powodziami, sekwestrację dwutlenku węgla, regulację klimatu, utrzymują różnorodność biologiczną i dostarczają drewna, korka i szyszek. Są także domem dla zwierzyny oraz źródłem owoców, grzybów i innych zasobów odnawialnych. Ponadto stanowią miejsce odpoczynku i rekreacji dla człowieka. Lasy są dobrem ogólnospołecznym, a racjonalna gospodarka zasobami leśnymi ma istotny wpływ na jakość życia i dobrobyt człowieka (Copa i Cogeca 2014).

W 2015 roku w Polsce wskaźnik lesistości ukształtował się na poziomie $30,2 \%$ i - jak wynika $\mathrm{z}$ danych przedstawionych na rysunku 2 - była to wartość znacznie niższa niż w krajach, które charakteryzowały się najwyższym udziałem powierzchni lasów w swojej powierzchni ogółem, a więc Finlandii $(65,6 \%)$, Szwecji (64,0\%) i Słowenii (61,6\%), lecz także niższa od średniej dla wszystkich krajów UE (36,8\%).

Zasoby wody słodkiej w odpowiedniej ilości oraz właściwej jakości są niezbędne do rozwoju ekosystemów, życia ludzkiego, a także do podejmowania róż- 


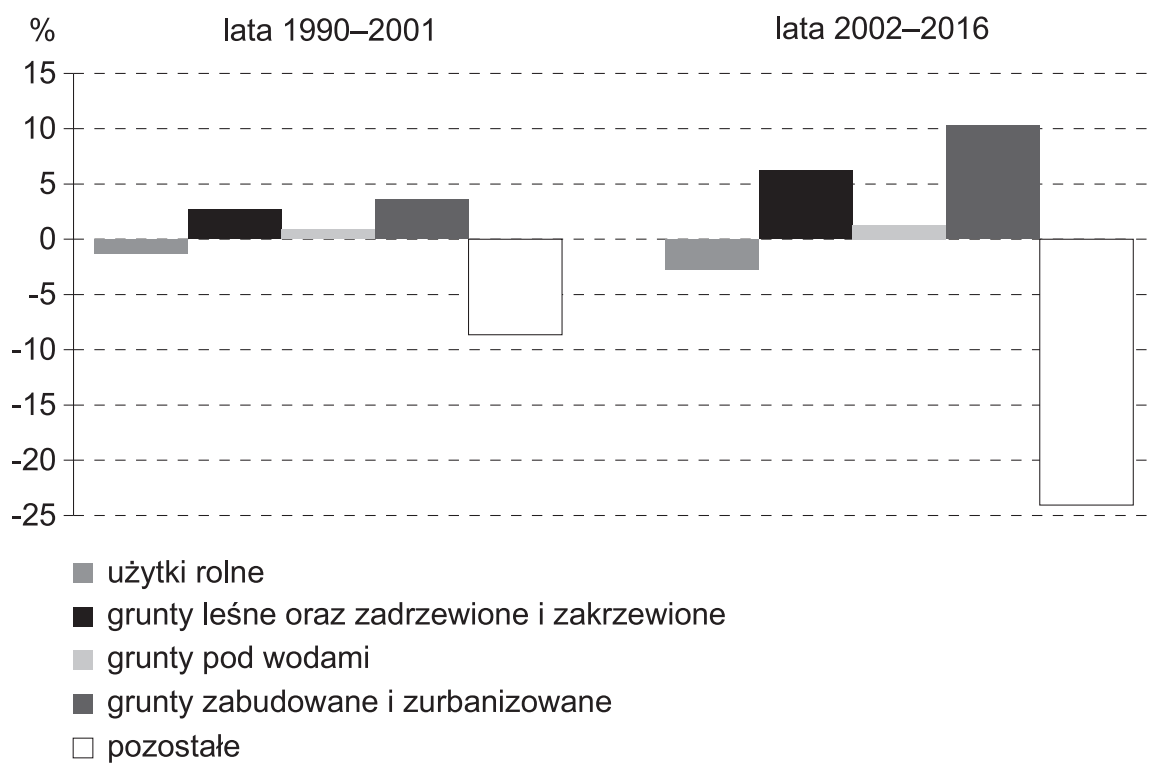

Rysunek 1. Zmiany użytkowania gruntów

Źródło: dane Głównego Urzędu Geodezji i Kartografii.

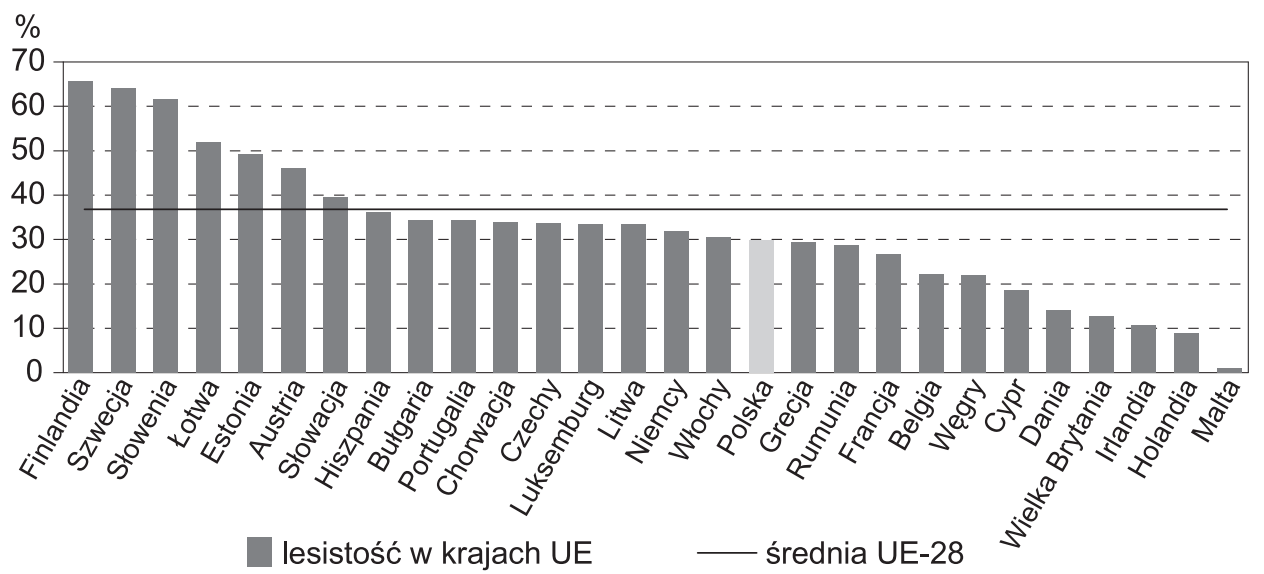

Rysunek 2. Wskaźnik lesistości w krajach Unii Europejskiej

Źródło: opracowanie własne na podstawie bazy danych Eurostatu, www.ec.europa.eu (dostęp: 26.04.2017)

nego rodzaju działań gospodarczych. Dostępność tej wody ma również istotne znacznie dla stanu zdrowia ludności. Pogłębiające się niedobory wody wynikają z wielu czynników. Jednym z nich jest stały rozwój gospodarczy, który przyczynia się do wzrostu poziomu życia ludności, jednak jego skutkiem ubocznym 
jest rosnące zapotrzebowanie na wodę. Jej zasoby są nadmiernie i nieracjonalnie eksploatowane, zarówno w ramach zużycia przez indywidualnych konsumentów, jak i przez rolnictwo i przemysł. Dlatego konieczna jest nie tylko jej ochrona przed zanieczyszczeniami, lecz także racjonalne i oszczędne gospodarowanie jej zasobami (Kobyłka 2011).

Do oceny stopnia wykorzystania tego zasobu może posłużyć wskaźnik eksploatacji wody (WEI - ang. Water Exploitation Index). Przedstawia on udział średniego rocznego poboru wód słodkich w długookresowych średnich wielkościach zasobów wód słodkich (GIOŚ 2011, s. 12). Wartość wskaźnika przekraczająca 20\% oznacza występowanie zjawiska stresu wodnego. Wskaźnik WEI dla krajów, dla których był dostępny w bazie Eurostatu w 2012 roku', został przedstawiony na rysunku 3.

Analizując dane zaprezentowane na rysunku 3, można stwierdzić, iż tylko w trzech krajach — na Cyprze, Malcie i w Hiszpanii — wskaźnik ten przekroczył $20 \%$, co oznacza występowanie w tych miejscach zjawiska stresu wodnego. W Polsce w 2012 roku wskaźnik eksploatacji wody ukształtował się poniżej 20\%, osiągając poziom $18,2 \%$.

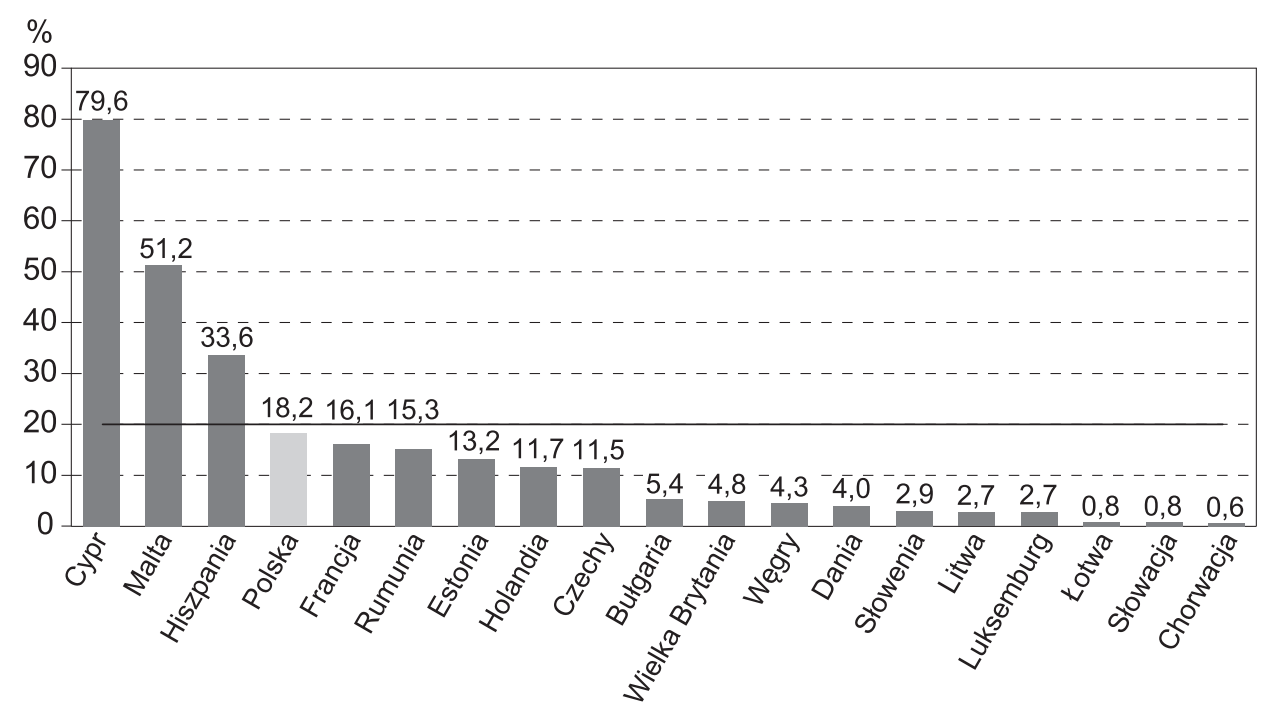

wskaźnik WEI — próg powyżej $20 \%$ - zjawisko stresu wodnego

Rysunek 3. Wskaźnik eksploatacji wody (WEI)

Źródło: opracowanie własne na podstawie bazy danych Eurostatu, www.ec.europa.eu (dostęp: 5.04.2017).

Kolejnym istotnym problemem, który wpływa na życie ludzi, są występujące w powietrzu zanieczyszczenia pyłowe. Pył zawieszony jest mieszaniną bardzo

1 Dane dostępne dla 19 państw. 
małych cząstek stałych i ciekłych, złożoną ze związków organicznych i nieorganicznych. Najgroźniejszy dla zdrowia człowieka jest pył o średnicy ziaren mniejszej niż 2,5 $\mu \mathrm{m}$. Krótkookresowe narażenie na pył $\mathrm{PM}_{2,5}$ może powodować wystąpienie objawów chorobowych w grupach szczególnie wrażliwych (na przykład u małych dzieci, kobiet w ciąży, osób starszych), natomiast długotrwałe narażenie zwiększa ryzyko zachorowania na choroby układu oddechowego oraz krwionośnego całej populacji. Negatywne skutki oddziaływania pyłu $\mathrm{PM}_{2,5}$ na zdrowie ludzi zależą od jego składu chemicznego. Im więcej w pyle jest związków organicznych, takich jak na przykład wielopierścieniowe węglowodory aromatyczne, czy metali ciężkich, tym narażenie na negatywne skutki jego oddziaływania jest większe (GIOŚ 2016, s. 20-21).

Od 2010 roku obserwowano w Polsce pozytywne tendencje w postaci systematycznego spadku wielkości wskaźnika średniego narażenia ludności na pył $\mathrm{PM}_{2,5}$. W 2015 roku wyniósł on jenak $23 \mu \mathrm{g} / \mathrm{m}^{3}$, co oznacza, że w dalszym ciągu znacząco przekracza poziomy wyznaczone ze względu na ochronę zdrowia - zarówno wartość pułapu stężenia ekspozycji $\left(20 \mu \mathrm{g} / \mathrm{m}^{3}\right)$, jak i krajowy cel redukcji narażenia $\left(18 \mu \mathrm{g} / \mathrm{m}^{3}\right)$ (rysunek 4).

$\mu \mathrm{g} / \mathrm{m}^{3}$

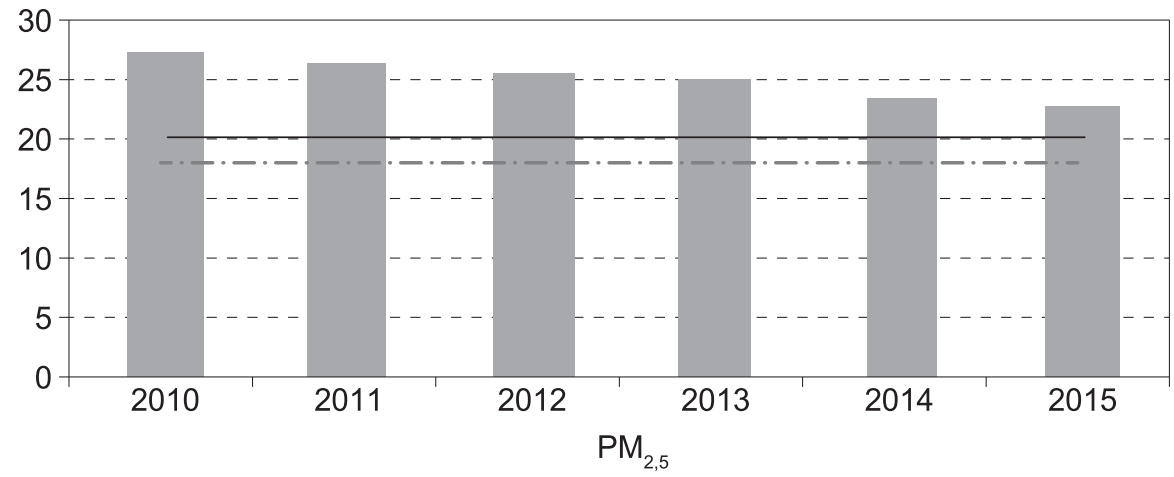

krajowy wskaźnik średniego narażenia na pył

— pułap stężenia ekspozycji

-.- krajowy cel redukcji narażenia

Rysunek 4. Wskaźnik średniego narażenia ludności na pył $\mathrm{PM}_{2,5}$

Źródło: Główny Inspektorat Ochrony Środowiska.

Według Europejskiej Agencji Środowiska w Polsce w 2013 roku ekspozycja na pył $\mathrm{PM}_{2,5}$ doprowadziła do ponad 48 tys. przedwczesnych zgonów. Wynik ten klasyfikuje nasz kraj na trzecim miejscu wśród państw UE, za takimi krajami, jak Niemcy i Włochy. 
Innym skutkiem zanieczyszczeń powietrza jest powstanie ozonu w przyziemnej warstwie atmosfery (tak zwanego ozonu troposferycznego). Ze względu na ochronę zdrowia ustalono, że wartość docelowa ozonu w powietrzu nie powinna przekraczać $120 \mu \mathrm{g} / \mathrm{m}^{3}$. W 2015 roku średnia liczba dni z przekroczeniami poziomu docelowego przez stężenia 8-godzinne ze wszystkich stacji wyniosła 24 dni i była jedną z wyższych wartości od 2003 roku (rysunek 5). Jeśli przeanalizuje się poszczególne typy stacji, będzie można zauważyć, iż najgorsza sytuacja występuje na stacjach pozamiejskich. Oznacza to, że ozon ma bardziej negatywny wpływ na jakość życia mieszkańców terenów wiejskich niż miast.

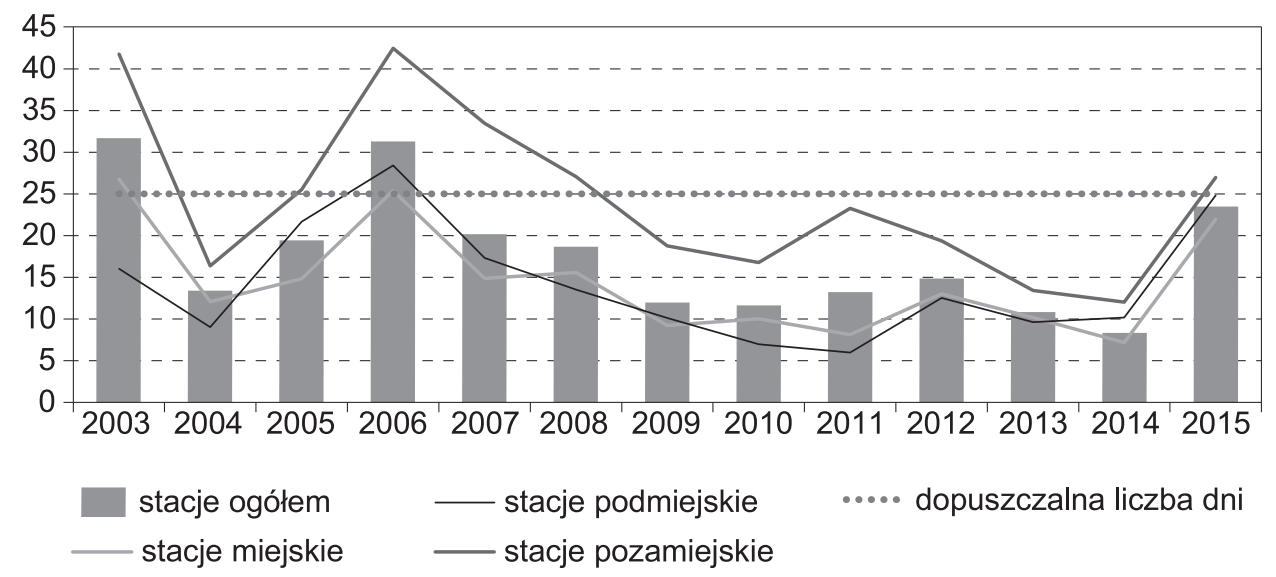

Rysunek 5. Średnia liczba dni z przekroczeniami wartości $120 \mu \mathrm{g} / \mathrm{m}^{3}$ przez stężenia 8-godzinne ozonu według typu stacji pomiarowej*

* Dane z pełnych serii pomiarowych uzyskane na stacjach monitoringu w ramach Państwowego Monitoringu Środowiska (PMŚ).

Źródło: opracowanie własne na podstawie danych Głównego Inspektoratu Ochrony Środowiska.

Narażenie na ozon może powodować negatywne skutki zdrowotne w postaci podrażnienia oczu czy wzrostu wrażliwości na infekcje, może również przyczynić się do zmniejszenia wydolności płuc, nasilenia astmy lub innych chorób płuc. Ponadto organizm człowieka broni się przed przedostającym się do płuc ozonem i zmniejsza ilość wdychanego tlenu, co w konsekwencji może powodować nasilenie chorób układu krążenia. Ozon może także powodować senność, bóle głowy i znużenie oraz spadek ciśnienia tętniczego krwi. Ponadto podwyższone stężenia ozonu niszczą roślinność i przyspieszają korozję materiałów (GIOŚ 2016, s. 30-31). Europejska Agencja Środowiska oszacowała, że ekspozycja na ozon doprowadziła w 2013 roku do ponad 1 tys. przedwczesnych zgonów w Polsce.

Kolejnym czynnikiem, który wpływa na jakość życia ludzi, jest emisja gazów cieplarnianych. Charakterystyczne właściwości tych gazów wywołują tak zwa- 
ny efekt cieplarniany, który w przyszłości może przyczynić się między innymi do zmniejszenia zasobów wodnych, zwiększenia częstotliwości i intensywności powodzi, topnienia lodowców, erozji gleby, a także nasilenia takich zjawisk, jak trąby powietrzne, gradobicia, fale mrozów czy też nadmierne upały (IOŚ). Ponadto zjawisko efektu cieplarnianego jest ściśle związane ze sposobem życia ludzi, szczególnie w krajach rozwiniętych gospodarczo (Zmiany klimatu 2006, s. 6).

W 2014 roku Polska z wielkością 347,5 mln t ekwiwalentu $\mathrm{CO}_{2}$ znalazła się na piątym miejscu wśród najbardziej emisyjnych krajów UE. Z danych zaprezentowanych na rysunku 6 wynika, że największy wzrost emisji gazów cieplarnianych w krajach Wspólnoty, w stosunku do roku bazowego z protokołu z Kioto, nastąpił na Malcie (50,9\%), Cyprze (43,9\%) oraz w Hiszpanii (17,5\%), natomiast najgłębszy spadek emisji odnotowano na Litwie (59,3\%), w Rumunii $(56,1 \%)$ oraz Lotwie $(55,9 \%)$. Polska w tym okresie odnotowała spadek emisji gazów cieplarnianych o $19,4 \%$ (rysunek 6).

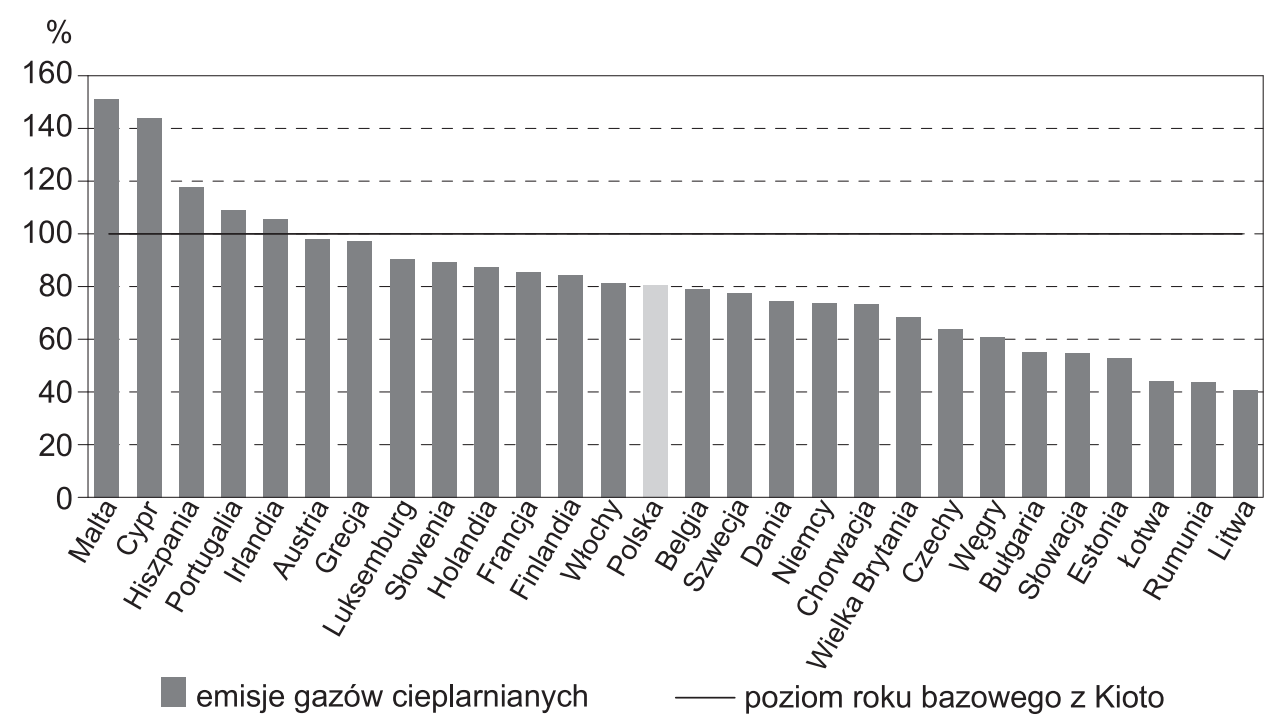

Rysunek 6. Emisje gazów cieplarnianych

Źródło: opracowanie własne na podstawie danych Eurostatu, www.ec.europa.eu (dostęp: 26.04.2017).

Na jakość i komfort życia człowieka wpływa również hałas. Jego nadmierne odziaływanie może prowadzić do stanów chronicznego przemęczenia, stresu, chorób układu krążenia, osłabienia układu immunologicznego lub autonomicznego układu nerwowego (GIOŚ 2014, s. 129).

W wypadku hałasu przemysłowego oceny zmian klimatu akustycznego dokonywane są na podstawie okresów pięcioletnich. Analizując dane przedstawione na 


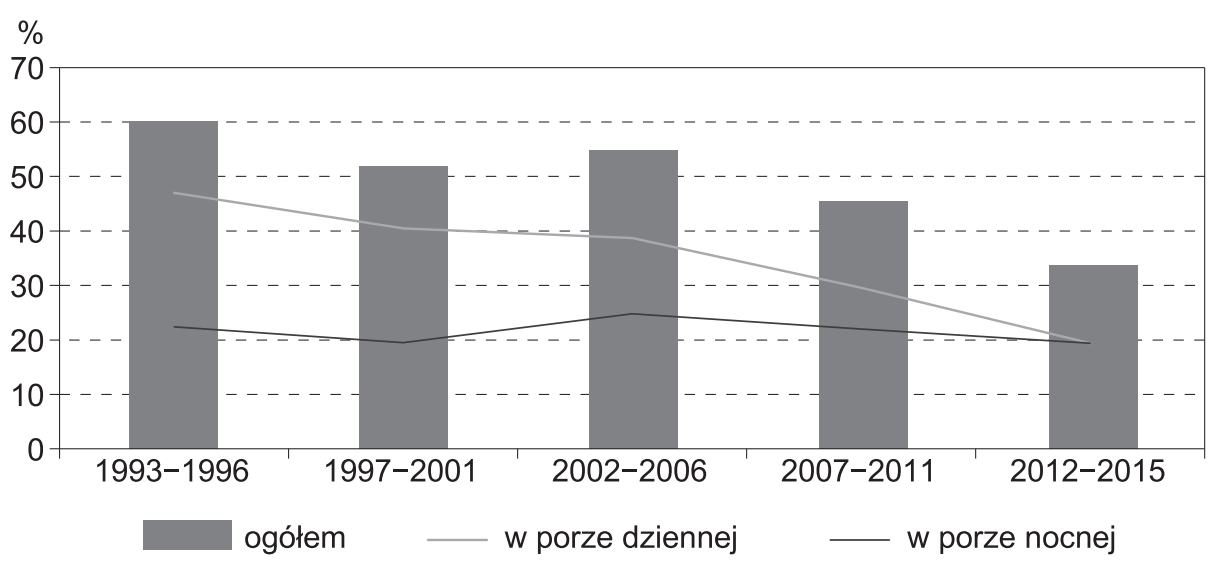

Rysunek 7. Odsetek zakładów przekraczających dopuszczalne poziomy w zakresie hałasu przemysłowego

Źródło: opracowanie własne z map akustycznych na podstawie danych Głównego Inspektoratu Ochrony Środowiska i Państwowego Monitoringu Środowiska.

rysunku 7, można zauważyć pozytywne tendencje w zakresie zmniejszania się odsetka zakładów przekraczających dopuszczalne poziomy hałasu. W latach 19931996 stanowiły one 60,2\% wszystkich jednostek, podczas gdy w latach 2012-2015 ich udział wyniósł tylko 33,7\%. Spadek nastąpił zwłaszcza w odniesieniu do pory dziennej (z 47\% do 19,4\%).

Hałas drogowy, w związku z szybkim rozwojem sieci dróg oraz rosnącą liczbą samochodów, stanowi główne zagrożenie dla ludności zamieszkującej tereny zurbanizowane. Długotrwałe narażenie na hałas drogowy może początkowo powodować irytację, zaburzenia snu, który jest potrzebny do należytego funkcjonowania człowieka, oraz depresję. W skrajnych przypadkach może doprowadzać do groźniejszych dla zdrowia skutków związanych ze wzrostem ryzyka wystąpienia nadciśnienia tętniczego i chorób układu krążenia. Wraz z rozwojem transportu oraz infrastruktury drogowej problem staje się coraz poważniejszy. Dlatego też konieczne jest monitorowanie hałasu w środowisku i działania na rzecz jego ograniczenia (GIOŚ 2016, s. 64).

W 2012 roku 53,5\% ludności miast powyżej 100 tys. mieszkańców była narażona na nadmierny hałas o poziomie powyżej $55 \mathrm{~dB}$ w porze dzienno-wieczorno-nocnej (wskaźnik $\mathrm{L}_{\text {DWN }}$ ). W porze nocnej (wskaźnik $\mathrm{L}_{\mathrm{N}}$ ) sytuacja kształtowała się nieco korzystniej, ponieważ na przekroczenia poziomu hałasu powyżej $50 \mathrm{~dB}$ eksponowanych było 36,6\% ludności miast (rysunek 8). 


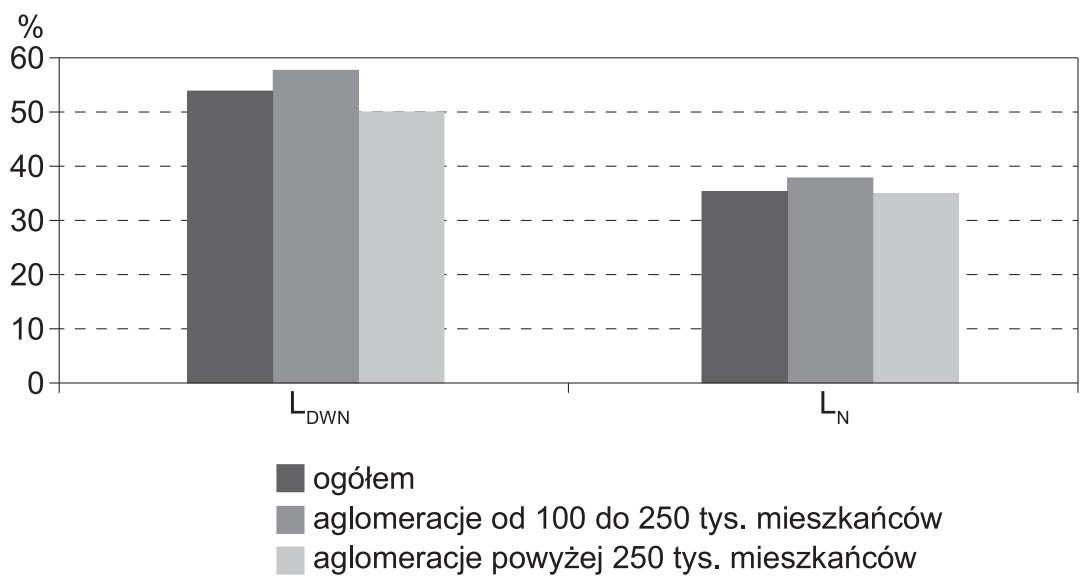

Rysunek 8. Odsetek osób narażonych na hałas drogowy w aglomeracjach powyżej 100 tys. mieszkańców w 2012 roku

Źródło: opracowanie własne z map akustycznych na podstawie danych Głównego Inspektoratu Ochrony Środowiska i Państwowego Monitoringu Środowiska.

Analizując wyniki badania hałasu drogowego w aglomeracjach w poszczególnych klasach poziomów dźwięku, można zauważyć, że zarówno w porze dziennej, jak i nocnej największy odsetek osób narażony był na przekroczenia hałasu do $5 \mathrm{~dB}$ (odpowiednio 20,4\% i 17,5\%) (rysunek 9).

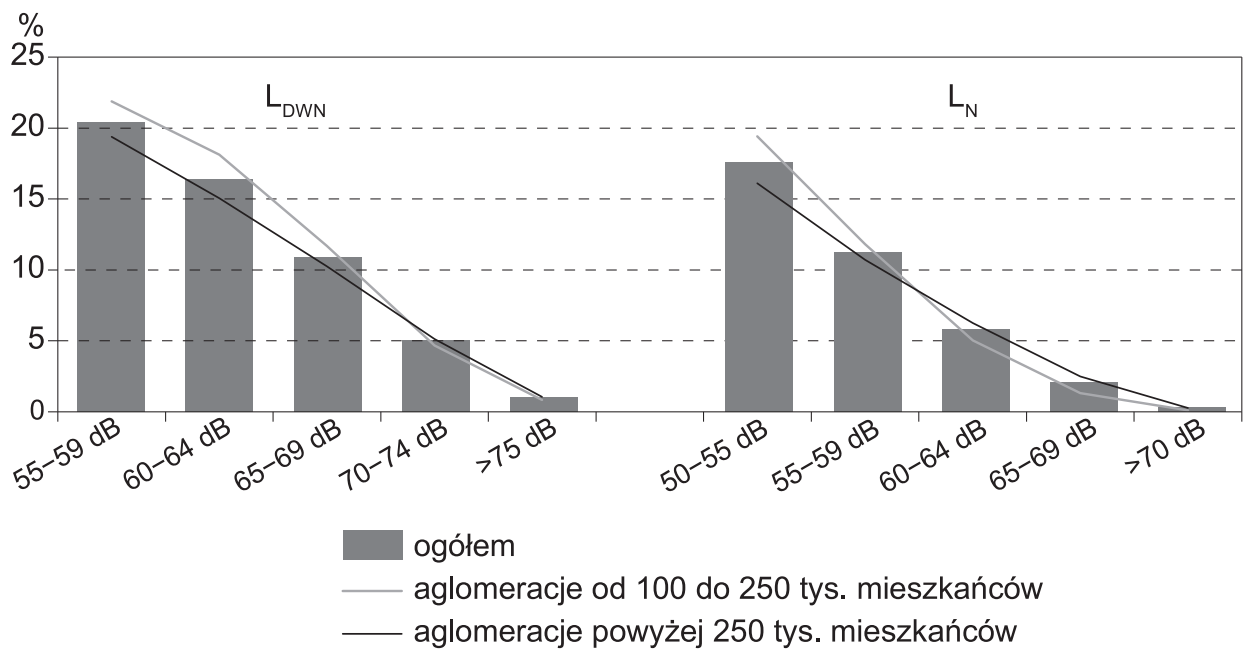

Rysunek 9. Odsetek osób narażonych na hałas drogowy w aglomeracjach powyżej 100 tys. mieszkańców w poszczególnych klasach poziomów dźwięku w 2012 roku

Źródło: opracowanie własne z map akustycznych na podstawie danych Głównego Inspektoratu Ochrony Środowiska i Państwowego Monitoringu Środowiska.

Ekonomia — Wroclaw Economic Review 23/4 (2017)

(C) for this edition by CNS 
Problem hałasu rozpatrywany jest również w Europejskim Badaniu Dochodów i Warunków Życia (EU-SILC - European Union Statistics on Income and Living Conditions). Badanie to określa między innymi wysokość odsetka gospodarstw domowych odczuwających subiektywny (w odniesieniu do miejsca zamieszkania) nadmierny hałas w mieszkaniu, pochodzący od sąsiadów lub z zewnątrz (spowodowany ruchem ulicznym, przez zakłady przemysłowe, działalność gospodarczą). Wyniki tego badania, przedstawione na rysunku 10, wskazują, że odsetek gospodarstw odczuwających nadmierny hałas z roku na rok spada (z poziomu 21,4\% odnotowanego w 2005 roku do 12,4\% w 2015 roku). Może to sugerować, że społeczeństwo przyzwyczaja się coraz bardziej do otaczającego je hałasu. Dane wskazują również, iż gospodarstwa domowe z dziećmi w mniejszym stopniu odczuwają hałas niż gospodarstwa domowe bez dzieci.

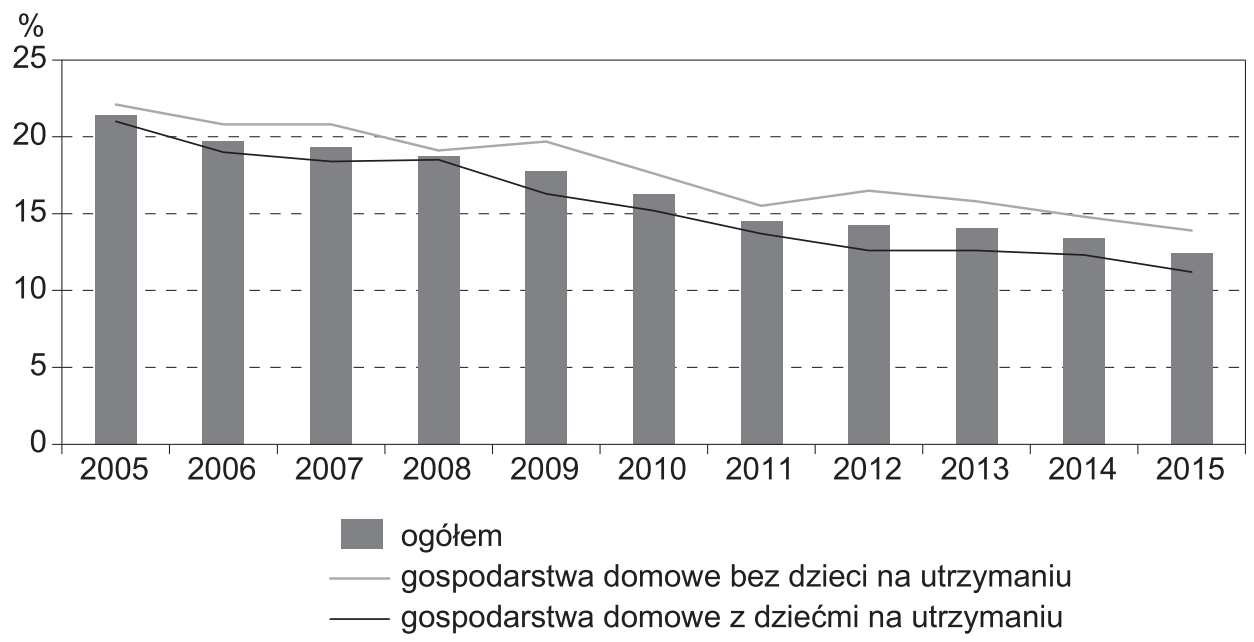

Rysunek 10. Odsetek gospodarstw domowych odczuwających nadmierny hałas

Źródło: opracowanie własne na podstawie bazy danych Eurostatu, www.ec.europa.eu (dostęp: 5.04.2017).

Rolnictwo ekologiczne wpływa pozytywnie nie tylko na środowisko naturalne, ale przede wszystkim na zdrowie ludzi. Ten rodzaj rolnictwa dostarcza na rynek żywność wysokiej jakości oraz kreuje nowe wzorce konsumpcji. Rozwój rolnictwa ekologicznego świadczy o wzroście świadomości konsumentów w kwestii zdrowego żywienia. 


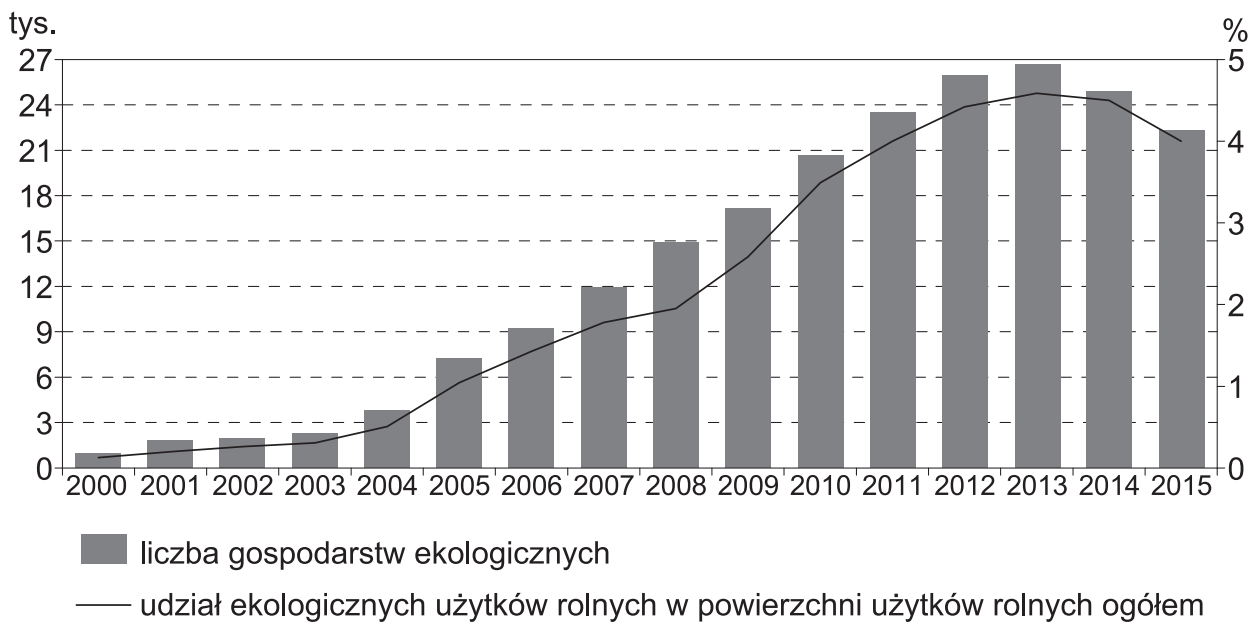

Rysunek 11. Gospodarstwa ekologiczne i powierzchnia ekologicznych użytków rolnych

Źródło: Inspekcja Jakości Handlowej Artykułów Rolno-Spożywczych.

Lata 2000-2013 charakteryzowały się stałym wzrostem liczby gospodarstw ekologicznych oraz powierzchni ulokowanych w ich obrębie użytków rolnych. Tendencja ta uległa zmianie od 2014 roku, gdy po raz pierwszy w skali roku zaobserwowano spadek liczby gospodarstw ekologicznych oraz ich powierzchni. Ta niekorzystna tendencja utrzymała się również w 2015 roku, w którym liczba gospodarstw i ich powierzchnia zmniejszyła się odpowiednio o 10,3\% i 11,7\% (rysunek 11).

\section{Podsumowanie}

Sposób, w jaki wykorzystuje się zasoby naszej planety, powoduje degradację środowiska i zmniejsza dostępność kapitału naturalnego dla przyszłych pokoleń. W celu zapewnienia odpowiedniej jakości życia oraz długofalowego dobrobytu potrzebny jest proces ,zazielenienia” gospodarki.

Analizując zaprezentowane w opracowaniu wielkości mierników, które mogą służyć do opisu jakości życia mieszkańców, a są wykorzystywane w monitorowaniu stanu zielonej gospodarki, można stwierdzić, że pomimo poprawy jakości powietrza w Polsce istotnymi problemami nadal pozostają wysokie stężenie ozonu troposferycznego i ponadnormatywne stężenie pyłu $\mathrm{PM}_{2,5}$, a także wysoka emisja gazów cieplarnianych. W ostatnich latach na rzecz ochrony jakości powietrza oraz zmniejszenia emisji gazów cieplarnianych wprowadzono wiele instrumentów redukcji zanieczyszczeń powietrza, na przykład w zakresie poprawy jakości paliw czy też działalności kontrolnej (GIOŚ 2011, s. 68).

Obserwowany poziom hałasu w środowisku w Polsce wskazuje z jednej strony na wzrost zagrożenia, a $z$ drugiej — na jego ograniczenie $i$ wystąpienie ten- 
dencji malejących w zakresie hałasu przemysłowego. Wzrost zagrożenia hałasem drogowym jest związany przede wszystkim z gwałtownym przyrostem liczby samochodów w kraju. Wymaga to podejmowania skutecznych rozwiązań prawnych i konsekwentnych działań w celu jego ograniczenia.

W ciągu ostatnich dwóch lat w naszym kraju odnotowuje się spadek zarówno liczby gospodarstw ekologicznych, jak i powierzchni ekologicznych użytków rolnych. Zdaniem Inspekcji Jakości Handlowej Artykułów Rolno-Spożywczych (IJHARS) przyczyn tego zjawiska należy upatrywać między innymi w konsolidacji rynku oraz zmianie programów rolnośrodowiskowych. Aby zapobiec tej negatywnej tendencji, zdaniem IJHARS należy stworzyć korzystniejsze warunki prawno-ekonomiczne dla tej formy działalności (Styczek-Kuryluk 2016).

Na tle krajów UE Polska wypada dość niekorzystnie w zakresie lesistości. Wskaźnik ten ukształtował się na poziomie niższym od średniej unijnej. W związku z tym zwiększanie lesistości jest trwałym elementem polityki przestrzennej, ekologicznej i gospodarczej kraju. Najbardziej jednoznacznie potrzeba wzrostu lesistości została ujęta w Polityce Leśnej Państwa (MOŚZNiL 1997) jako jeden z istotnych jej celów, którego realizacja powinna doprowadzić do zwiększenia lesistości kraju do $30 \%$ w roku 2020 i 33\% po roku 2050 oraz uporządkowania granicy rolno-leśnej z korzyścią dla wartości krajobrazu, funkcjonowania lasów i rolnictwa (Łazowy 2014, s. 2).

Sytuacja Polski kształtuje się korzystniej, biorąc pod uwagę gospodarkę wodną. Mimo że w ostatnich latach obserwowana jest stabilizacja poboru wód, a wartość wskaźnika eksploatacji wody (WEI) systematycznie się zmniejsza, to w dalszym ciągu kształtuje się on poniżej $20 \%$, czyli poziomu „stresu wodnego”. Niezbędne jest jednak podejmowanie działań w zakresie racjonalizacji gospodarowania wodą, gdyż wobec obserwowanych zmian klimatycznych może wystąpić w Polsce deficyt wody.

Analiza informacji dotyczących kierunków wykorzystania powierzchni kraju wykazała, że w latach 2002-2016 najbardziej wzrosła powierzchnia obszarów zabudowanych i zurbanizowanych, a także powierzchnia gruntów leśnych oraz zadrzewionych. Zmniejszeniu uległa natomiast powierzchnia pozostałych gruntów i użytków rolnych. Niezmiernie ważne w polityce przestrzennej państwa jest utrzymanie właściwej (racjonalnej) struktury użytkowania przestrzeni pozwalającej na zaspokajanie potrzeb mieszkańców. Należy przy tym pamiętać, że część przekształceń przestrzeni ma charakter w zasadzie niezmienny (na przykład zmiana rolniczej przestrzeni w zurbanizowaną).

Przedstawiony w opracowaniu zestaw miar nie wyczerpuje analizowanego tematu i obejmuje jedynie niewielki zakres czynników mających wpływ na jakość życia, które są monitorowane w ramach badania zielonej gospodarki. Mogą one być wykorzystywane również do monitorowania jakości życia, głównie w aspekcie środowiskowym. 


\section{Bibliografia}

Copa i Cogeca (2014), Europejskie lasy przyczyniają się do rozwoju obszarów wiejskich, wrzesień, Bruksela, http://www.copa-cogeca.be/Download.ashx?ID=1274409 (dostęp: 26.05.2017).

Gillingham R., Reece W.S., Analytical Problems in measurement of the quality of life, „Social Indicators Research" 1-4, 1980, s. 91-101.

Główny Inspektorat Ochrony Środowiska (GIOŚ) (2011), Stan Środowiska w Polsce. Sygnaty, Biblioteka Monitoringu Środowiska, Warszawa.

Główny Inspektorat Ochrony Środowiska (GIOŚ) (2014), Stan Środowiska w Polsce - Raport 2014. Sygnaty, Biblioteka Monitoringu Środowiska, Warszawa.

Główny Inspektorat Ochrony Środowiska (GIOŚ) (2017), Stan Środowiska w Polsce. Sygnaty 2016, Biblioteka Monitoringu Środowiska, Warszawa.

Inspekcja Ochrony Środowiska (IOŚ), Zmiany klimatyczne, http://www.gios.gov.pl/stansrodowiska/gios/get_pdf/pl/front/zmiany_klimatyczne (dostęp: 26.05.2017).

Kobyłka A. (2011), Malejące zasoby wody: globalny problem przyszlości, 12 marca, http://www.psz. pl/169-raporty/malejace-zasoby-wody-globalny-problem-przyszlosci (dostęp: 26.05.2017).

Łazowy S. (2014), Koniec zalesień? O problemach realizacji „Krajowego program zwiększania lesistości”, materiały z Panelu Ekspertów „Rozwój” — Lasy i Gospodarka Leśna jako Instrumenty Ekonomicznego i Społecznego Rozwoju Kraju, Instytut Badawczy Leśnictwa, http:// www.npl.ibles.pl/sites/default/files/referat/referat_s.lazowy.pdf (dostęp: 26.05.2017).

Ministerstwo Ochrony Środowiska, Zasobów Naturalnych i Leśnictwa (MOŚZNiL) (1997), Polityka leśna państwa, Warszawa.

OECD (2011), Towards Green Growth: Monitoring Progress OECD Indicators.

Słaby T. (1990), Poziom życia, jakość życia, „Wiadomości Statystyczne”, nr 6, s. 8-14.

Styczek-Kuryluk M. (2016), Kolejny spadek liczby eko gospodarstw i powierzchni eko użytków rolnych, 21 lipca, http://ekoarka.com.pl/kolejny-spadek-liczby-eko-gospodarstw-i-powierzchni-eko-uzytkow-rolnych/ (dostęp: 26.05.2017).

Urząd Oficjalnych Publikacji Wspólnot Europejskich (2006), Zmiany klimatu - o co w tym wszystkim chodzi?, Luksemburg.

Urząd Statystyczny w Białymstoku (US Białystok) (2016), Wskaźniki zielonej gospodarki w Polsce, Białystok.

Ekonomia — Wroclaw Economic Review 23/4 (2017)

(C) for this edition by CNS 